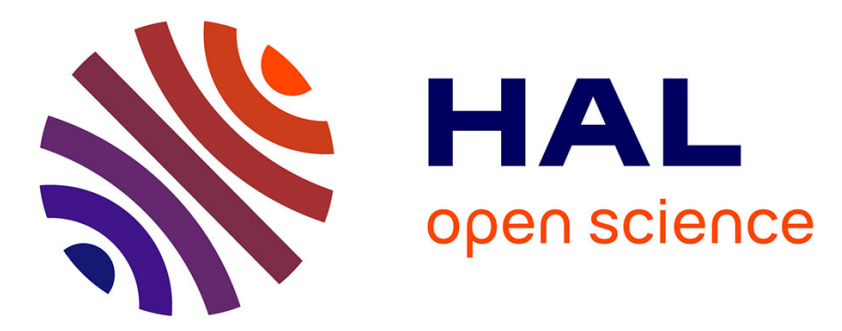

\title{
Soil micromorphological data from traditional and experimental agriculture \\ Anne Gebhardt
}

\section{To cite this version:}

Anne Gebhardt. Soil micromorphological data from traditional and experimental agriculture. Archaeological sediments and soils : analysis, interpretation and management, Barham, Macphail (eds), Archetype press, London 25-40, 1995. hal-02275501

\section{HAL Id: hal-02275501 \\ https://hal.science/hal-02275501}

Submitted on 30 Aug 2019

HAL is a multi-disciplinary open access archive for the deposit and dissemination of scientific research documents, whether they are published or not. The documents may come from teaching and research institutions in France or abroad, or from public or private research centers.
L'archive ouverte pluridisciplinaire HAL, est destinée au dépôt et à la diffusion de documents scientifiques de niveau recherche, publiés ou non, émanant des établissements d'enseignement et de recherche français ou étrangers, des laboratoires publics ou privés. 


\section{Soil micromorphological data from traditional and experimental agriculture}

\section{Anne Gebhardt}

\section{Introduction}

Recent soil micromorphological investigations on palaeosols buried under well dated archaeological structures, specific pit and ditch infills, and colluviums in Brittany, show that the present landscape, developed in Brittany since the last glacial period, has been intensively affected by human activity since the Neolithic (Gebhardt 1990, 1993).

Micromorphological pedofeatures have provided much data on soil evolution in Brittany (palaeopedogenesis, degree of erosion) and help us to understand the way a site was affected by human interference (deforestation, agriculture, etc). Over and above the general tendency of some profiles to acidify under human impact, different types of nonrcontemporaneous edaphic evolution can be distinguished. There are typical examples of soil degradation initiated by human clearance as early as the Neolithic. In some cases of profile rejuvenation, probably caused by the general erosion of the loessic blanket, only a slight soil degradation has been observed. Deforestation also instigated the rise of watcr-tables, causing soil hydromorphism.

The micromorphological study of Brittany's palaeosols demonstrates the complexity of ancient pedological phenomena which occur in soils. However, this interesting problem encourages research, especially the study of Holocene palaeosols.

The analysis of some colluvial deposits showed that although commencing with the first deforestations, colluviation was probably further encouraged by agricultural activity and the loamy character of the soils. The variation in thickness observed in the downslope deposits may also be related to the duration of cultivation.

In receiving features, ditches, lynchets etc, colluviated material can become trapped and develop pedologically in buried but poorly sealed conditions. In the example studied, comparison between ditches may reveal differences in the microstructure of the infilling, even on the same site and under the same modern agricultural treatment. In that case, specific pedofeatures may be related to the different function of each ditch and the evolution of its fill. As a result even ditch maintenance practices could be determined.

Until now, results from palaeosol studies have provided more data on anthropogenic deforestation, landuse management over a long period and the influence of early agriculture on the environment (soil acidification, erosion) than on the types of agricultural implements used in the past and how they affected the soil.

In the case of unprotected soils and infill sediments, the interpretation of micro-pedofeatures is more difficult than for buried palaeosols. Possibly more care must be taken in their interpretation, especially in modern, heavily cultivated areas. Here, more than ever, micromorphological data should be used within a multidisciplinary framework in order to compare data from other investigative methods (charcoal, seeds or pollen analysis). Because the preservation of such organic residues can be very poor in some archaeological contexts, it is important to compare micromorphological data from archaeological structures with an experimental and traditional data base when attempting to explain the function of structures. This may be the only way to classify the pedofeatures formed Within infills dating to the use of the structure, and those formed after its use, as for example by subsequent 1ong-term agriculture.

\section{Why conduct experiments in archaeological soils?}

Although there is useful modern agricultural research (Barratt 1968; Collins and Larney 1987; Dexter 1979; Jongerius 1983; Kooistra 1987; Pagliai 1987) which can be used as analogues (Macphail et al.1990), there are few experimental data on the impact of ancient implements and ancient field management methods on the soil microstructure. Micromorphological descriptions of ancient soils are given using the most recent nomenclature (Bullock et al. 1985). Archaeological and environmental interpretations themselves are based on micropedological investigations carried 
out within a soil science context (Barratt 1971; Jongerius 1970, 1983; Pagliai and La Marca 1979) or deduced from micromorphological observation carried out within an archaeological pluridisciplinary context (Courty et al. 1989).

In the case of ancient cultivated fields, only a few micromorphological interpretations have been carried out on the kind of tool used (hoe, ard, plough, spade), and how this affects soil microstructure.

At Strathallan, for example, counting of the dusty clay coatings present in the palaeosols permitted Romans and Robertson (1983) to form the hypothesis that in the upper $6 \mathrm{~cm}$ of soil concentration of coatings was due to hoe cultivation at the mound site. At the Henge site, the concentration of coatings at $12 \mathrm{~cm}$ was interpreted as resulting from ard cultivation, since an ard ploughs deeper than a hoe. It is not known, however, if this result can be applied to all ancient cultivated sites. The realisation that this hypothesis had to be checked was an important initial impetus for the start of an experimental research programme.

Experimental investigations are now strongly linked to the archaeological world (see the Actes of the international symposium Experimentations en archéologie: bilan er perspectives [Firmin and Devos-Firmin 1991]), and are as diverse as experiments on architecture (DevosFirmin and Firmin 1991 ; Sainty and Schnitzler 1985; Reynolds 1984), lithic material and everyday life conditions (Coles 1979).

Experimental agriculture in archaeology has recently appeared in Europe, for example in the study of plant change through domestication (Willcox 1992). To this end seed collections have been made, ancient crops have been cultivated, and their yields studied (Reynolds 1984; Luning and Meurers-Balke 1980; Anderson 1992). Experimenters have also been interested in the use of reconstructions of ancient ploughing and harvesting tools, and to study the microwear traces which forrn on them (Reynolds 1984; Lerche 1986; Anderson 1992).

Because experiments sometimes take a considerable time to produce results, an alternative research avenue is the study of traditional societies and their technologies (Leroi-Gourhan 1971, 1973; Pétrequin 1984; Butler 1992). However, in all these investigations, except for a few works on ethno-pedology (Wilshusen and Stone 1990) and on experimental furrow shape (Lerche 1986), soils have been largely ignored, and research seldom deals with the impact of tool and agricultural management on the soil.

\section{Some experimental results}

ln order to compare the microstructures of archaeological soils with experimental and traditionally cultivated soils, the same sampling and laboratory techniques should be used for both. For methodology, see Macphail and Goldberg this volume; Matthews this volume; Gebhardt 1990, 1993; Courty et al. 1989.

The results described below come from several sites in north west Europe (Fig. 1). In order to maintain the best pedoclimatic unity for these particular experiments, and also to allow better comparison with archaeological sites studied in Brittany, the experiments are divided roughly into two groups: the experimental sites of Butser (United Kingdom), Hambacher Forst (Germany), Grignon (France), Melrand (France) and the traditional sites of Malguénac (France) and Melrand (France).

\section{Micromorphological analysis of soil structure modification caused by different (ancient) cultivation implements}

The aim of this programme (see Gebhardt 1990, 1992) was to study the modifications in structure and porosity produced in soil by various cultivation implements, as both structure and porosity are important factors in agricultural soils (Fedoroff 1986). The structure in soil thin-sections was observed through a stereoscopic microscope.

The four experimental sites and their soil types are as follows:

- Butser Ancient Farm (United Kingdom): a calcareous colluvium (cambisol, F.A.Oi 1975; sol 
brun: Duchaufour 1983) ploughed (depth: $30 \mathrm{~cm}$ ) with a reconstructed Iron Age type ard since 1970 (Reynolds 1984);

- Hambacher Forst (Germany): an alfisol (F.A.O. 1975; sol bmn lessivé: Duchaufour 1983) developed in loessic-loam under forest, the soil of which was ploughed (5 to $10 \mathrm{~cm}$ deep) several times within one year with an ard pulled by two people. Between each of the eight rounds of four criss-cross ard ploughing (N/S, E/W, NW/SE, NE/SW) the field surface was trampled by three to four people for five minutes (Meurers-Balke 1985; Tegmüller pers.comm.). A plot nearby, worked with a motor cultivator (Ap horizon: $10 \mathrm{~cm}$ deep) was also studied for companson;

- Grignon Forest (France, INA-PG) : an alfisol (F.A.O. 1975; sol bmn lessivé: Duchaufour 1983) developed on a loessic loam was worked (5 to $10 \mathrm{~cm}$ deep) with a wooden hoe of Neolithic type (reconstructed from the Champréveyre type, Switzerland) and heavily watered over a period of a single month in order to accelerate the pedological processes (about 2000 litres in July 1986);

- the Dehérain plots (France INA-PG) : established by agronomists on a cambisol (F.A.O. 1975; sol brim: Duchaufour 1983) developed on calcareous colluvium under grassland (INA-PG, unpublished) to study the influence of different types of manuring on crop yield. Several plots have been worked with a cultivator (20 cm deep) or a spade (Ap horizon: $10 \mathrm{~cm}$ ).

The micromorphological impact of four ploughing tools was then compared to uncultivated reference profiles at each site 1 the hoe (Grignon), the ard (Butser, Hambacher Forst), the spade (Dehérain) and the cultivator (Dehérain, Hambacher Forst).

For each kind of implement, the degree of soil compaction, porosity, ped form and shape, depth of organic matter burial, and the depth of tool impact which marked the depth of the Ap horizon, were compared (Gebhardt 1990, 1992).

At Dehérain, Butser and Grignon, the initial structure of the soil was very compacted and well structured, with characteristic 'birdfoot-shaped' cracks (3 or 4 radial junctions) isolating soil peds.

Significant biological activity occurred, suggested by faunal pellets, root remains and its high porosity formed mainly of channels and burrows. The loessic loam at Hambacher Forst is very compact, but less porous than the other sites.

After cultivation, the soil at Dehérain, Butser and Grignon became looser, comprising clods of different sizes according to the tool employed (a.rd or spade: mean clod size $10 \mathrm{~mm}$; cultivator: mean clod size $15 \mathrm{~mm}$ ) mixed with smaller angular peds. In the middle of the biggest clods, flle original soil structure can still be preserved. At Hambacher Forst, the soil microstructure collapsed because the original A horizon structure was weak, but numerous rounded peds (mean diameter 2.5 $\mathrm{mm}$ ) were observed in the groundmass compacted by the a.rd. The bottom of the ploughed horizon is compacted into a lmm thick 'pan' formed during the one year experiment. This initial feature is related in origin to plough pans in modem arable soils (Jongerius 1970; Collins and Larney 1987). The motor cultivator created clods with straight, cleanly broken edges.

The hoeing experiment at Grignon showed an increase in 'star-shaped' porosity. This was certainly caused by excessive watering of the plots over too short a time (Courty and Trichet 1988). Input of organic matter in the form of pure straw, humified straw, or stable litter did not affect the structure of any horizon, worked or not. The only evidence ofthis input was an increasing quantity of organic fragments, more or less incorporated into the soil.

Traces of faunal activity seem to be more visible in thin section in the uncultivated control soils and unmanured plots, than in the manured plough horizons. Whatever the treatment, the excrcments of microfauna (oribatids, enchytraeids) were more obvious than mesofauna (earth- 
worms). Cultivating the soil (ploughing, wetting and drying effects) obscures or destroys most of the micromorphological traces of faunal activity. Pellets and crumbs are broken and/or coalesce into more compactly structured peds. The biological fabric remains visible deeperin the soil profile, beneath the level of ploughing.

\section{A traditional ploughed field (see Gebhardt 1990)}

Ethnological survey allowed us to find in Malguénac (Morbihan, France), an ancient field which had been ploughed with a horse-drawn plough, although for the last fifty years the land has been used as a cow pasture.

As the profile had not been disturbed since cultivation ceased, it is possible to recognise the typical horizons of a distric cambisol (F.A.O. 1975; brun acide: Duchaufour 1983) developed on weathered granite. The profile has a brown-yellow sandy loam Ap (15 to $20 \mathrm{~cm}$ ) horizon, including $10 \mathrm{~cm}$ long 'comma shaped' fragments of B horizon brought up by plough action. Under the Ap, there is a yellowish sandy-loam B horizon (15 cm thick). The boundary is generally sharp for the 'comma' fragments, sharp between Ap and B, and diffuse between B and the weathered granite.

Under the microscope, we can recognise the following:

- The ploughed Ap horizon includes fragments of the anient leached A1 horizon material (1 .5 $\mathrm{mm}$ ) and yellowish fragments of B horizon (size: 0.5 to $2 \mathrm{~cm}$, Fig. 2a). Microfaunal activity (enchytraeids pellets) is Well developed in all this horizon. Earthworm channels are rare, concentrated at the top of the profile, and indicate the recent rise in pl-I due to manuring or pasture development;

- At around $25 \mathrm{~cm}$ depth, in the B horizon, it is possible to recognize relict fragments of an ancient Bt horizon characterised by some limpid clay void coatings and infillings, which are sometimes layered and/or fragmented. At this level some other void clay coatings are very dusty and unlayered (Fig.2b). They are more recent than the limpid coatings. In some places the groundmass is also dusty. The dusty deposits can be related to the ancient cultivation of the field (Jongerius 1970). Biological activity is represented by enchytraeid pellets.

There is no obvious structural evidence of ancient ploughing, because the microstructure has probably been destroyed by biological activity since its pastural use.

\section{Other soil micromorphological features relating to experimental agricultural practices and human activities}

Lann-Gouh (near Melrand, Morbihan, France) is a medieval (10th century AD) deserted village situated on the edge of a granitic plateau dominating the river Sarre (Chalavoux 1987). Since 1986, the scientific investigation of this site by J. Chalavoux has been the focus of original multidisciplinary investigations of the medieval site and experiments related to archaeological problems (Chalavoux et al. 1990).

\section{The pig pasture}

On the north-east slope of the Lann-Gouh plateau, pig breeds, genetically close to the ancient 'Pores de Bayeux ' breeds, were bred in an open air forested enclosure. Great damage was caused by them in just a few weeks: very quickly, the soil surface was completely disturbed and small trees were uprooted. This provided an opportunity to compare the soil micrornorphological impact of the pig pasture with the untouched forest soil (Gebhardt 1990).

The forest soil profile (top $40 \mathrm{~cm}$ studied) is a distric cambisol (F.A.O. 1975; brun aeide: Duchaufour 1983) It has a dark-brown very bioturbated upper A0 organic horizon (3 cm deep, Fig.3a), with a slightly open porosity. The $10 \mathrm{~cm}$ deep brown homogenous $\mathrm{Al}$ horizon is also rich in weathered organic matter and includes roots. Microfaunal activity (numerous enchytraeid pellets) is 
intense in both upper horizons. The mineral B horizon is developed on the weathered granite. The junction between horizons is diffuse.

The pig pasture profile is essentially the same as the one in the forest, but is buried by a $15 \mathrm{~cm}$ thick compacted colluvial horizon (Fig.3b), formed by a mixture of organic horizon (Ao and $\mathrm{Al}$ ) and yellowish-brown compacted B horizon soil fragments. The boundary between the buried Ao horizon and the colluvium is sharp.

The result of pig action was to remove the field surface and to generate a colluvial deposit on the slope.

The threshing area (before and after ase)

At St Price in the same area of Lann-Gouh (Melrand, Morbihan), a threshing area was reconstructed in a farm yard with the help of retired farmers who had used traditional construction techniques in their youth (Chalavoux unpubl.).

The threshing area was constructed with loamy argillic gley soil collected from a local wetland, first mixed by horse trampling. A Fest Noz (typical breton dancing party) was organised in order to further pack the sediment in a $10 \mathrm{~cm}$ thick layer across the $7 \mathrm{~m}$ wide threshing area. Rye was threshed with ancient flails in a traditional way: straw bundles being arranged in a thick bed across the area before being threshed by farmers. Grain was collected by scraping the surface with a wooden scraper which would not damage the area's surface.

Sampling was carried out on this threshing floor, before and after the threshing, to provide control and post-threshing samples.

Micromorphological analysis showed very few differences between the two samples. The microstmcture of the threshing area is compact and the porosity is very low, suggesting greater compaction. Diatoms are numerous, often associated with organic matter coming from the marshy sediment. Phytoliths are also numerous, although the longer phytoliths appear to have been broken. The unlayered sediment shows an alternation of units rich or poor in fine material including some orientation of the plant fragments. This textural fabric reflects the repeated mixing of sediment during the construction of the area.

In contrast to what was expected, there is no cracking due to drying or compaction from threshing. The sediment appeared to have dried progressively through its homogeneous thickness. During threshing, the flail, which strongly beats the rye, has no influence on the area's constructed structure, or on the grain (rye grains were neither buried nor broken up during threshing).

The house floor

At Lann-Gouh, different dwelling floors were investigated. Inside a medieval house, pieces of a compacted earth were excavated. It was impossible to know if it was a naturally compacted or manmade earth floor, or to give any details on the way it was constructed.

Through the microscope, we compared this compacted earth with two other examples, gathered in the Lann-Gouh area:

- a traditional earth»floor from a house built last century, constructed by spreading successive layers of fine and coarse material;

- an experimental house earth floor, which resulted from natural soil being compacted by human and animal trampling.

The three earth floors looked different micromorphologically (Gebhardt 1990). The traditional house floor is mainly mineralogenic and well layered (Fig/la), whereas the experimental one is organic with pseudo-horizontal cracks (Fig/lb). The archaeological example, in contrast, is very homogeneous, with few cracks and looks like the soil beneath the other two examples (Fig.4c). It was concluded that the archaeological fragments are in fact from the top of the weathered granitic subsoil. 
Thus we can suppose that the inhabitants of the medieval house lived on a natural soil floor, from which the organic upper horizon had been removed. It simply became compacted by domestic trampling.

\section{Discussion}

This last example shows how important experimental and traditional data can be in archaeological interpretation. It was possible to give an interpretation on the formation ofhouse floors. which would have been impossible on the basis of archaeological data alone. However, we found that experimental data can he very difficult to use in archaeological interpretations unless some care is taken.

\section{The requirement for pedoclimatic homogeneity in experimental design}

In the case of the house floors, comparisons were very precise because the comparative material was gathered in exactly the same pedoclimatic area.

Experimental results obtained from the experimental farms on calcareous soils were difficult to compare with archaeological sites studied in Brittany because the latter are located on granitic and metamorphic substrata.

For example, tillage micropedofeatures such as the dusty clay coatings described by Romans and Robertson ( 1983) were not observed at the four experimental cultivation sites (except for perhaps some concentration of textural feature at Hambacher Forst which will be discussed below). This lack of dusty clay formation is not a question of the length of experiment duration (clay translocation has been rapidly produced in laboratory experiments] see Dalrymple and Theocharopoulos 1987]) and the fields at Butser have been ploughed since 1974 (Reynolds 1984). Nor is it a question of quantity of rainfall (see Grignon above; Gebhardt 1992). Clay translocation occurs in decalcified soils (Duchaufour 1983). Most of the experimental profiles were not sufficiently decalcified. At Malguénac, where 25-30 cm deep tillage (plough) had taken place, dusty clay coatings were observed because the profile was sufficiently decalcified.

Even if these experimental results were not comparable to archaeological sites in Brittany, they were very useful in interpreting structural break-down by tillage at Ashcombe Bottom in England (Macphail et al. 1990 ; Macphail 1992).

\section{The experimental site's historical background}

At Harnbacher Forst, the presently wooded experimental site was first deforested during the Roman period (Meurers-Balke pers. comm), which would also have led to dusty clay coating formation. Thus, the few thin layers of dusty clay observed at 12-14 cm depth in the voids of the experimental profile which probably relate to experimental ard tillage (Macphail et al. 1990), have to be carefully differentiated from the historical dusty features, also present in the control forest profile (Gebhardt 1990). For example, by examining the relationship and hierarchy of coatings and associated porosity patterns.

In fact today's European landscape is the result of intensive human activity during prehistoric and historic periods. Modern soils used for experiments are unfortunately often already the product of at least 5,000 years of increasingly intensive cultivation.

\section{The time scale}

It is difficult to accelerate experiments. In the case of Grignon, intensive watering over a short time transformed the natural soil evolution. At the planning stage of the experiment, because the soil water absorbtion capacity was not taken into account, the experimental plots were accidentally transformed into a 'paddy field' soils with atypical spongy microstructure. Even so, this result has been exploited to interpret wet condition in some archaeological soils in Brittany (Gebhardt 1990).

\section{The 'zero time' control sample}

Until now (exept for Grignon, see above), micromorphological analysis of experimental cultivated 
profiles started after at least one year of experimental farming. So we never had the 'zero time' sample, which refers to the soil before experimentation. The only way to obtain a control reference soil was to sample just beside the experimental field. This should provide a good comparison provided that the experiment started less than a couple of years before, and is situated in a relatively 'natural' area (for example a forest in the case of Hambacher Forst, or Lann-Gouh). In Deherain or Butser, experiments are quite mature, and the only 'zero point' available was recently uncultivated grassland along the footpath next to the sampled plots.

In all cases, it is diffieult to say how similar the control sample is to a real 'zero time'. It is also quite impossible to experiment in ancient agriculture under the same original conditions found by the first farmers. This does not necessarily matter, however (see Macphail et ul. I990), as the presence of dusty clay in the control forest profile at Hambaeher Forst illustrates that the use of control samples helps to differentiate micromorphological features belonging to the on-site soil history from those caused by experimentation and/or past tillage.

Ageing of microstructure A further question is 'Does microstructure evolve with time?' When the fields are not buried quickly after abandonment, normal pedogenesis may change structure and disturb pedofeatures At Malguénae, for example, after fifty years of abandonment as pasture, ancient tillage features are still recognisable in terms of deep horizon units ploughed up to the surface. On the other hand, typical tillage microporosity has been disturbed by recent bioturbation.

In the case of burial, there may well be structural transformation due to the weight of the overburden (barrow, burial mound, wall, bank). Even now these fundamental influences on palaeosols are not yet fully studied (Macphail and Goldberg this volume). Under the Wareham Experimental Earthwork (Dorset) for example, compaction of the very top of a buried humo-ferric podzol was by thirty per cent (Fisher and Macphail I985), and at Overton Down Experimental Earthwork (Jewell I963; Jewell and Dimbleby 1966) compaction seems to have occurred rapidly in the last sixteen years of the thirty two year old experiment (Macphail and Goldberg this volume). In Brittany, prehistoric buried soils were often eroded (Gebhardt I990, I993). Moreover, before burial the organic horizon seems not have been very thick, perhaps having been probably disturbed by deforestation or tillage.

This can also make it difficult to compare fresh (unburied) experimental tillage data with cultivation features from archaeological (buried) sites.

\section{Sample representation}

The last question is the sampling and environmental factor. In the case of the pig pasture, for example, one sampled area on the slope suggested a strongly colluvial effect. But when we looked at the field, many roots where dug out by the pigs. What kind of profile microstructure would we have observed in an enclosure on flat land'? More sampling at differents levels of the slope wouldprovide a more representative idea of damage to the soil profile caused by pig trampling.

\section{Conclusion}

We can conclude by a description of the ideal conditions for experimental research in agrarian archaeology.

Experiments should be run in the same area, within a unified pedoclimatic context, similar to the one investigated archaeologically. The ideal experiment should be followed from its beginning with a 'zero time' soil sample and long enough so that the soil has time to record the changes due to the type of cultivation carried out. An example of this is difficult to find because, up until now, experiments in archaeology have often been short and relatively unconcemed with soil changes.

Instead of attempting to accelerate experiments, recent and traditional cultivated fields and related features can be studied. These have the advantage of still being well understood by the extant farming population and of having functioned over a sufficiently long period for typical 
features to develop clearly. Ideally, this should be done in parallel with an historical investigation of farmers who previously farmed the land.

Several sampling locations for the same experiment are necessary to obviate sampling uncertainties.

In fact, in order to be most efficient, this experimental and ethno-archaeological research should be part of a global regional programme to study the evolution of the arable landscape. Experiments help to answer archaeological questions. Soil processes are very long and studying traditional or extant structures can provide a good opportunity for obtaining answers more quickly.

As the historian M. Bloch (1931) said, in order to interpret the past, it is good to look at a past very near the present.

\section{Acknowledgements}

The author wishes to thank all the archaeologists and experimental research workers who allowed access to their material and data. Many thanks to R. I. Macphail for collaborative discussions and help with writing this article and with my English.

\section{References}

Anderson, P. C. 1992 Experimental cultivation, harvest and threshing of wild cereals and their relevance for interpreting the use of Epipalaeolithic and Neolithic artefacts. In: Anderson, P.C. (ed) Préhisloire de I 'Agrieulmre.' nouveller approches experimenmles er erhnographiques, 179-209. Monographie du CRA No. 6. Editions du CNRS. Paris: Centre Nationale de la Recherche Scientifique.

Barratt, B.C. 1968 Micromorphological observations on the effects ofland use differences on some New Zealand soils. The New Zealand Journal of Agricttltural Research, 11 (l) , lOl-130. Soil Bureau publication 408.

Barratt, B.C., 1971 A micromorphological investigation of structural changes in the top soil of Patamahoe clay used for market gardening. New Zealand Journal of Science 14(3), 580-598.

Bloch, M. 1931 (reprinted 3rd edition 1988) Les caractères originaux de l'histoire rurale française. Paris : A. Colin.

Bullock, P., Fedoroff, N., Jongerius, A., Stoops, G., and Tursina, T. 1985 Handbook for Soil Thin Section Description. Wolverhampton: Waine Research Publication.

Butler, A. 1992 Pulse agronomy: traditional systems and implications for early archaeology. In: Anderson, P.C. (ed.) Préhistoire de l'Agriculture: nuuvelles approches experimenzales et ethnographiques, 67-78. Monographie du CRA No. 6. Editions du CNRS. Paris: Centre Nationale de la Recherche Scientifique.

Chalavoux, J. 1987 La ferme archéologiques de Melrand. Dalc'homp sonj, Revue historique bretonne 20, 35-37.

Chalavoux. J. 1992 La ferme Archéologique de Melrand. Bilan d‘activité 1988-I991, unpublished. Chalavoux, J., Gebhardt, A. and Le Cabec, Y. 1990 De la fouille à l'expérimentation en passant par les archéosciences: l'exemple de la micromorphologie, Revue d'Archéométrie 14. 17-22. Coles, J. 1979 Experimental Archaeology. London : Academic Press.

Collins, J.F. and Lamey. F.J. 1987 Micromorphological observations of compacted horizons (cultivation pans) from various horizon in Irish tillage soils. in: Fedoroff, N., Bresson. L.M. and M.-A. Courty (eds) Soil Micromorphology, 451-458. Plaisir: Association Francaise pour l'Etude du Sol.

Courty, M.-A., Goldberg, P. and Macphail, R. 1. 1989 Soils and Micromorpholugy in Archaeology. Cambridge : Cambridge University Press.

Courty, M.-A. and Trichet, J. 1988 Application dc la micromorphologie à la caractérisation des sols anciens cultivés. Le colloque Franco-Soviétique sur l'Archéologie de l’Asie Centrale de origines à l'Age du Fer , 237-241. Paris : de Boccard.

Dalrymple, J. B. and Theocharopoulos, S.P. 1987 Experimental construction of illuviation cutans (channel argillans) with differing morphological and optical properties, in: Fedoroff, N., 
Bresson, L.M. and M.-A. Courty (eds) Soil Micromorphology, 245-250. Plaisir: Association Fransaise pour l'Etude du Sol.

Devos-Firmin, M. F. and Firmin, G. 1991 Une fenne gauloise a Parchéodrome de Beaune (Côtes d’Or). Archéologie Aujourd’hui, Archéologie expérimentale - La terre L2. 190-204.

Dexter, A. R. 1979 Prediction of soil structure produced by tillage. Journal of Terramechanics 16 (3), 117-127.

Duchaufour, P. 1983 Pédogénese et classification. Pédologie, t.1. Paris : Masson. F.A.O. 1975 Soil map of Europe. Paris 1 UNESCO.

Fedoroff, N. 1986 Un plaidoyer en faveur de la paléopédologie. Bulletin de l‘AFEQ, 3/4, 195-204.

Firmin G., and Devos-Firmin, M. F. (eds) 1991 Archéologie Aujourd’hui, Archéologie expérimentale - La terre L2, Actes du Colloque Expérimentations en archéologie: bilan et perspectives, Beaune, avril 1988. Paris: Errance.

Fisher, P. F. and Macphail, R. I. 1985 Studies of archaeological soils and deposits by micromorphological techniques. In: Feiller, N., Gilbertson, D.D., and Ralph N.G.A., Palaeoenvironmental Investigations : Research Design, Methods and Interpretation. 93112. British Archaeological Reports International Series 258. Oxford: BAR.

Gehhardt, A. 1990 Evolution du paléopaysage agricole dans le nord-ouest de la France. Apport ale la micromorphologie. These de l’Université de Rennes 1.

Gebhardt, A. 1992 Micromorphological analysis of soil structural modification caused by different cultivation implements. In: Anderson, P.C.(ed.) Prehistoirc de l'Agriculture: nouvelles approches experimentales et ethnographiaues, 373-392. Monographie du CRA No. 6. Editions du CNRS. Paris: Centre Nationale dc la Recherche Scientifique.

Gebhardt, A. 1993 Micromorphological evidence of soil deterioration since the mid-Holocene at archaeological sites in Brittany, France. The Holocene 3 (4), 331-341.

INA-PG n.d. Les champs d'experience de la station agronomique de l'Inslitut National Agronomique de Paris-Grignon. Intemal duplicating. Unpublished.

Jewell, P. A 1963 The experimental earthwork on Overton Down, Wiltshire, I960. Research Committee of the British Association for the Advancement of Science.

Jewell, P.A. and Dimbleby, G.W. 1966 The experimental earthwork on Overton Down, Wiltshire, England; the first four years. Proceedings ofthe Prehistoric Society 3, 313-342.

Jongerius, A. 1970 Some morphological aspects of regrouping phenomena in Dutch soils. Geoderrna 4, 311-331.

Jongerius, A. 1983 The role ofmicromorphology in agricultural research. In: Bullock, P. and Murphy, C.P. (eds) Soil Micromorphology, 111-138. Berkhamsted: AB Academic Publishers. Kooistra, M.J . 1987 The effects of compaction and deep tillage on soil structure in dutch sandy loam soil. In: Fedoroff, N., Bresson, L.M. and M.-A. Courty (eds) SoilMicromorphology, 445-450. Plaisir: Association Frangaise pour l'Etude du Sol.

Lerche, G. 1986 Ridged fields and profiles of plough-furrows. Ploughing practices in Medieval and Post-Medieval Time. A study in Experimental Archaeology. Tools and Tillage 3, 131-156.

Leroi-Gourhan, A. 1971 L'Homme er la Matière. Paris: A. Michel.

Leroi-Gourhan, A. 1973 Milieu er technique. Paris: A. Michel.

Luning, J. and Meurers-Balke J. 1980 Experimenteller Gctreideanbau im Hambacher Forst, Gemeinde Elsdorf, Kr. Bergheim/Rheinland. Bonner Jahrbucher t180, 306-344.

Macphail, R.I . 1992 Soil micromorphological evidence of ancient soil erosion, In: Bell, M. and Boardman, J. (eds) Past and Present Soil Erosion. 197-215. Oxbow Monograph 22. Oxford: Oxbow Books.

Macphail, R.I. Courty, M.-A. and Gebhardt, A. 1990 Soil micromorphological evidence of early agriculture in north-west Europe. World Archaeology 22 (1), 53-69.

Meurers-Balke, J . 1985 Experimcntc zum Anbau und Zur Verarbeiterung prahistotorischer Getreidearten. Archaologische Informationert t. 8 (1), 8-17.

Pagliai, M. 1987 Effects of different managements practices on soil structure and surface crusting. 
In: Fedorof, N., Bresson, L.M. and M.-A. Courty (eds) Soil Micromorphnlogy, 415-422. Plaisir: Association Frangaise pour l'Etude du Sol.

Pagliai, M. and La Marca, M. 1979 Micromorphological study of crusts. Agrochimica 23,16-25. Pétrequin, P. 1984 Gens de l'eau, gens de la terre. Paris : Hachette.

Reynolds, P.J. 1984 Deadstock and livestock. In: Mercer, R. (ed.) Farming Practice in British Prehistory, 97-122. Edinburgh: Edinburgh Univerity Press.

Romans, J .C.C. and Robertson, L. 1983 The general effects of agriculture on the soil profile. In: Maxwell, G. S., (ed.) The Impact of Aerial Reconnaissance on Archaeology, 136-41.

CBA Research Report 49. London: CBA.

Sainty, J and Schnitzler, B. 1985 Construction experimentale d' une maison Néolithique a Holtzheim (Bas-Rhin). Cahiers Alsaciens d'Archéologie d'Art et d'Histoire t. XXVIII, 7-20.

Willcox, G.H. 1992 Archaeological significance of growing Near Eastem progenitors of domestic plants at Jalès (France). In: Anderson, P.C. (ed.) Prehistoire de l'Agriculture: nouvelles approches experimentales et ethnographiques, 159-177. Monographie du CRA No. 6.

Editions du CNRS. Paris: Centre Nationale de la Recherche Scientifique.

Wilshusen, R.I-I. and Stone, G.D. 1990 An ethno-archaeological perspective on soils. World Archaeology 22 (1), 104-l 14.

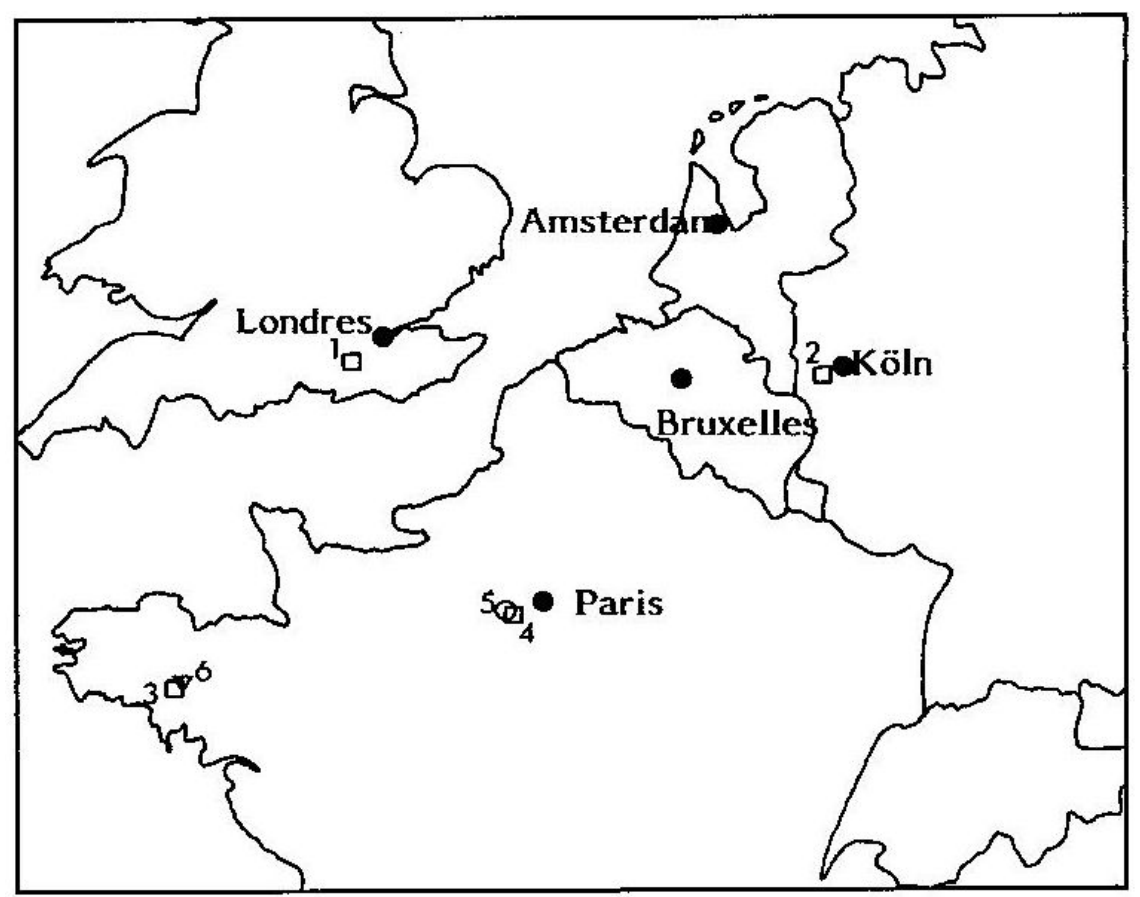

Fig.1. Site location. Archaeological experiments: 1. Butser; 2. Hambacher Forst; 3. LannGouh (Melrand); 4. Grignon Forest. Agronomical experiments: 5. Dehérain plots. Traditional reference sites: 6. St Price (Meirand) and Malguénac. 

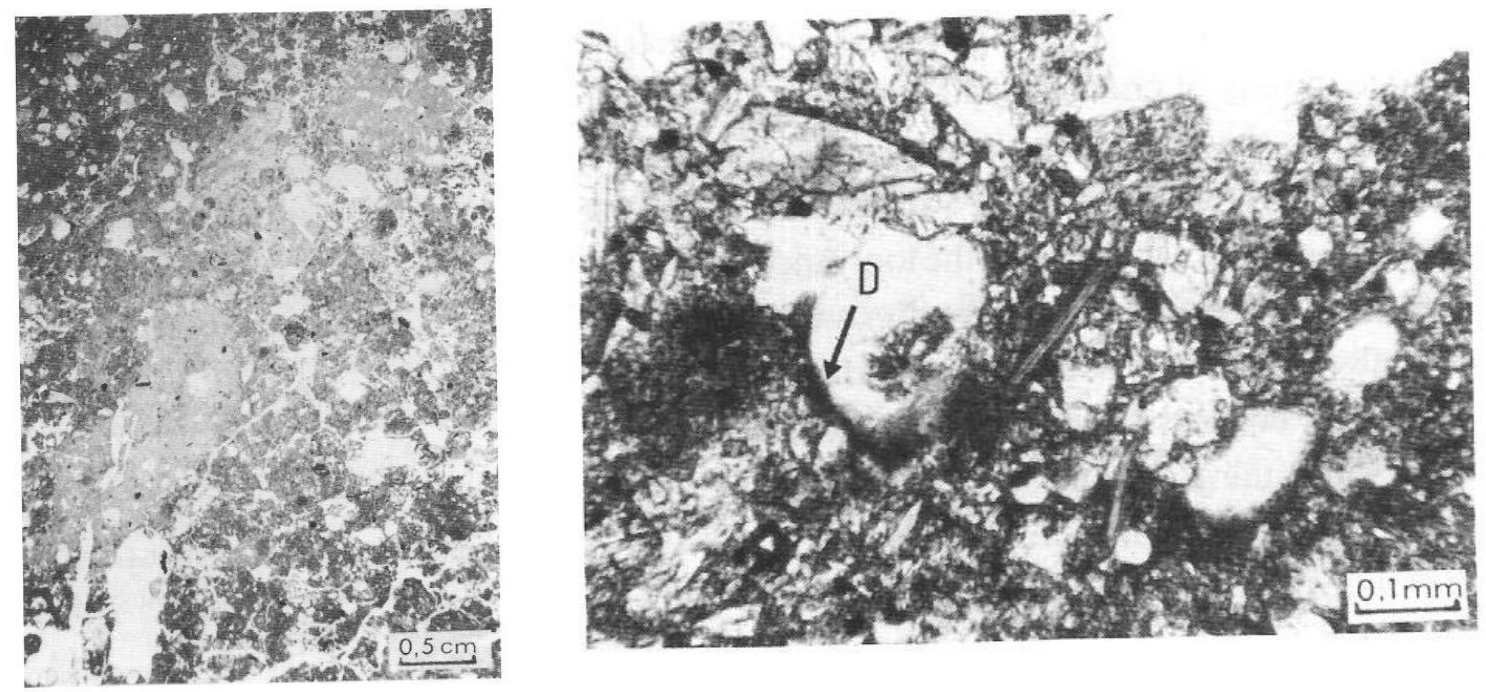

Fig. 2. The traditional ploughed field (Malguénac, Morbihan) a. (left) Fragments of sharply cut compacted and pale B horizon ploughed up by tillage and are now included in the more dark upper/4p horizon. b.(right) Dusty clay coatings infilling voids (D), observed in the B horizon (25/30 cm depth), and related to the ancient cultivation of the field.

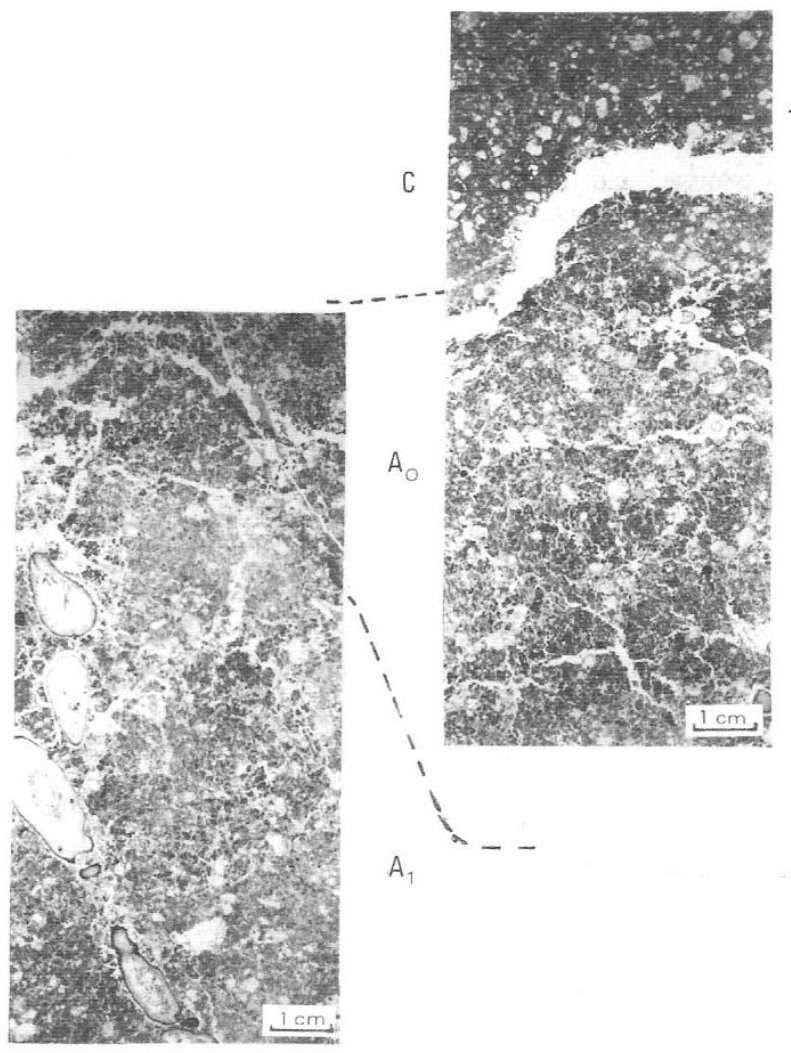

Fig. 3. The pig pasture (Lann-Gouh, Morbihan). The compacted colluviated sediment (C) burying the distric cambisol profile of the pig pasture $(3 \mathrm{~b})$, contrasting with the organic will strongly bioturbated horilons (A0, A1) of the control profile (311). The result of pig activity on the slope was to remove the topsoil and generate a colluvium covering the original profile downslope. 

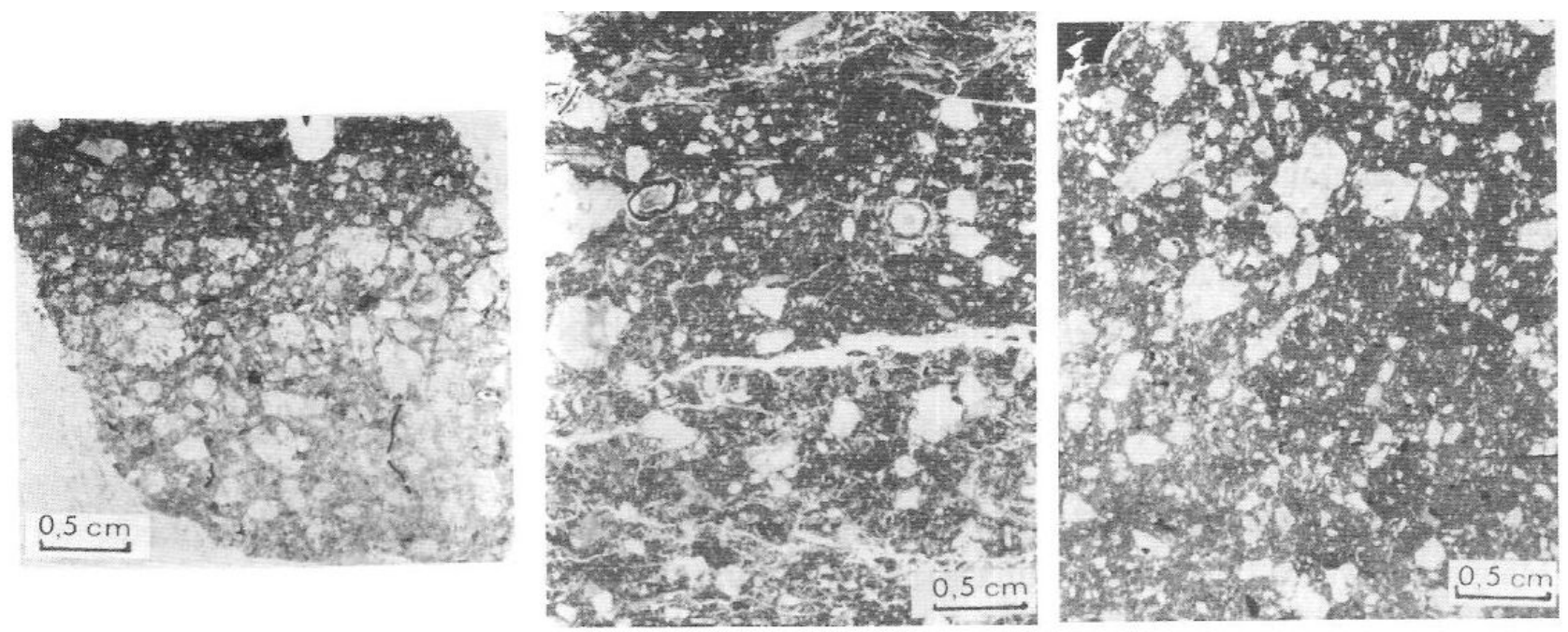

Fig. 4. Comparison of archaeological, traditional and experimental house-floors. (Lann-Gouh). (a,b,c from left to right) The slightly layered surface (4a) has to be related to the traditional earth floor construction. It was constructed by successive spreading of the fine and coarse material on a truncated soil (ie no vegetation and upper horizon ). Root and associated porosity are easily recognisable in the

experimental organic house -floor (4b). It results from a complete soil profile (ie with vegetation and upper horizons) which was compacted by daily human and animal trampling. A non-porous medieval house mineral soilfloor (4c), simply compacted by domestic trampling oftlze natural soil after removal of its organic upper horizons. 